\title{
Vertical Marketing Systems, Supply Chains and the New Indicators of Retailing's Significance
}

\author{
Zdenko SEGETLIJA ${ }^{1}$, Josip MESARIĆ ${ }^{1}$ and Davor DUJAK ${ }^{1}$ \\ 1 Josip Juraj Strossmayer University of Osijek, Faculty of Economics in Osijek, Osijek, Croatia
}

\begin{abstract}
In modern vertical marketing systems (i.e., in grocery sector), the greatest power is demonstrated by retail chains, and producers depend thereupon. This paper analyzes vertical marketing systems and the role of retailing therein. Specially analyzed is the power of retail chains' demand with regard to the entire supply chains they head, as well as the present-day new competition in retailing and modern business concepts related to the vertical marketing systems. Additionally, analyzed are also select indicators to examine the significance of retailing in an individual national economy. The purpose of this paper is to emphasize the new indicators of significance of retailing in economy with regard to the realized GDP, as a component of value chains. These indicators complement the usual retailing significance analyses from the point of view of its share in the number of employees and the number of companies.

From the conducted analysis, one may conclude that the vertical marketing systems become increasingly important, and retailing assumes a new role in economy in that sense. Thus, new indicators of retailing significance might also be necessary.
\end{abstract}

Key words - vertical marketing systems, retailing, retail chains, retail supply chain, significance of retailing.

\section{INTRODUCTION}

Based upon accessible literature, the paper initially analyzes the notions of marketing, marketing system, vertical marketing system, retailing, retail chain, supply chain and retailing supply chain, and then provides for the remarks on the applied indicators pertaining to the analysis of retailing significance in a distribution system and retailing significance for a national economy as a whole. Subsequently, provided are fundamental remarks on the development of concentration process and retailing demand power, as well as on business concepts of large-sized international retail chains, i.e., on contemporary development of vertical marketing systems, their significance for foreign trade, and the role of retailing therein in grocery sector.

Subsequently analyzed are select usual indicators pertaining to a retailing significance analysis within a distribution system of a given country, whereby new indicators are also suggested and examined.

Austria, Finland, Germany, Italy and the Netherlands are analyzed as market-developed countries. Croatia, Hungary, Slovakia, Czech Republic and Poland are included in the analysis among transitional countries. The data analyzed pertain to 2010, 2012, and 2013.

\section{RETAILING IN VERTICAL MARKETING}

To comprehend the notion of a vertical marketing system, the notion of marketing is initially explicated. Nowadays, a generally accepted understanding of marketing is the one defined by the American Marketing Association [1]: „the activity, set of institutions, and processes for creating, communicating, delivering, and exchanging offerings that have value for customers, clients, partners, and society at large."

Marketing is being developed in a market-oriented economy system.

A market-oriented system is a social network enabling a purchaser - vendor interaction. It incorporates all the rules and regulations, reputation, and tenets of the companies and individuals involved [15].

The recent marketing system considerations emphasize that marketing involves servicing the end consumer market while struggling with the competition in a general situation, for a company and its competitors dispatch their messages and products to the consumers directly or via marketing mediators. Naturally, the surrounding forces, demographic, economic, physical, technological, political-legal and the sociocultural ones, also influence all participants [9].

A marketing system may be observed from several viewpoints, so one elaborate on the following: 
- a marketing functions system;

- a marketing incumbent system (agents, participants);

- a marketing entrepreneurs and channels system [14].

A producer, wholesaler, reseller and retailer are most frequently adduced in the marketing channel system. E.g., this case is evident in the so-called "consumer marketing channel." However, a producer, business distributor, and a business client are adduced in the so-called „business marketing channels"[9].

Vertical marketing systems are created while connecting the functions of individual incumbents within a distribution channel. They are developed as a consequence of competitive fluctuations, so some business systems have been expanded while assuming the functions of other channel participants. It pertains to the expansion of activity in certain corporate or group systems, as well as to the development of cooperative forms.

According to McCammon (qtd. in [7]), marketing systems can be divided in conventional and vertical ones. Therefore, a fundamental division of vertical marketing systems in corporate, dirigated (administrative), and contractual ones is frequently mentioned (cf. [8]).

Nonetheless, horizontal and multichannel marketing systems are also being developed in addition to the vertical ones (cf. [10]).

In horizontal marketing systems, two or more vertically unconnected companies incorporate their resources or programs in order to utilize the opportunities on the market (e.g., the retailers within a mall, retailers in their supply commune, and banks with their consumer services within a supermarket).

However, if a product is sold to the purchasers who do not have the same status or to the purchasers on different markets (perhaps in different countries), possible is the formation of the socalled "multichannel systems." Nonetheless, the so-called "hybrid combination types," i.e., the hybrid marketing channels and multichannel retail, are nowadays becoming increasingly significant.

In hybrid marketing channels, the usage of a single channel is not efficacious enough. Namely, a multichannel architecture optimizes coverage, adjustment, and channel control while simultaneously minimizing expenditures and conflicts. Thus, various channels should be formed for the clients of different sizes [10].

On the other hand, multichannel retailing also refers to the forms of a complete Internet-based retail (or only to the enrichment of certain retail mix variables) in retailers' systems with the stores in a physical sense.

In such a way, a multichannel management is being developed; however, the notion is also used for the offline sale systems [16]. Therefore, the term is used for a sale with multiple sale modalities or for a parallel usage of multiple sale channels.

The distribution channel or marketing channel analyses are presently usually expanded to the analyses of entire supply (logistic) chains. Namely, entirely different concepts of collaboration and economic entities' connection have been developed in modern concentration processes, pertaining to the entire economic flows, from the first raw material producer to all production and distribution levels, up to consumption.

Therefore, the entire supply chain is vital for a company, consisting of both the "upstream" and "downstream" partners. It involves both the suppliers and mediators as well as the mediator clients, so that the so-called "value delivery networks" are being created (cf. [9]).

Thus, such an approach is important because a market success can only be assured by creating the entire value networks and not only by its downstream part, the distribution channels. Accordingly, the large-sized companies or groups nowadays manage their valve-creating chains. Supply Chain Management (SCM) has been developed in that sense.

Retail companies are the supply chain constituents. It is therefore necessary to define a distributive trade and retailing.

According to NACE [17], "distributive trade includes wholesale and retail sale (i.e., sale without transformation) of any type of goods, and rendering services incidental to the sale of merchandise." 
Thus, in wholesale, the purchasers are the receivers who use a merchandise for further economic activities, whereas in retail we speak about servicing an end consumer or an end user as a purchaser (cf. [12]).

With regard to the difficulties when distinguishing the retail from the wholesale, the Eurostat data [17] on the overall distributive trade (Section G - Wholesale and Retail Trade: Repair of Motor Vehicles and Motorcycles) and its constituents will be used in our analysis, as follows:

- Division 45 - Wholesale and Retail Trade and Repair of Motor Vehicles and Motorcycles;

- Division 46 - Wholesale Trade, Except Motor Vehicles and Motorcycles;

- Division 47 - Retail Trade, Except Motor Vehicles and Motorcycles.

A retail chain is a company transacting its business with multiple retail units under a joint proprietorship and usually has a centralized decision-making for the definition and implementation of its strategy. Some retail chains are the divisions of larger-sized corporations or holding companies [13]. Of course, the retail and wholesale activities are intertwined here.

In the retail importance analysis in a country, two indicators have been especially used for a long time (cf. [18]):

- retail share in overall employment;

- retail share in the overall number of economic entities (enterprises).

These indicators pertain to the retails' significance for distribution in a given country; however, one should take into consideration all the activities coordinated by the retail supply chains for an evaluation of significance of retail for the development of overall economy in a country, which have various impacts for each individual country. Therefore, the indicators of a relation between the realized GDP and the realized turnover in a distributive trade (especially the retail one) are also important in certain countries.

\section{RETAIL DEMANDS AND SUPPLY CHAINS}

In the concentration processes, the large-size retail companies could also take over the wholesale functions. Furthermore, the large-sized retail concerns have been positioned to dictate the prices to the producer companies due to the market power of concentrated commerce. E.g., in Germany that can be explained by an improved negotiation position of retail companies because of an increased supply volume, as well as, by the exclusion of wholesale and commercial mediation [21].

Nonetheless, the creation of large-size retail chains intensifies a competitive combat, so that various cooperative concepts are being developed as necessary, predominantly that of the Supply Chain Management (SCM), Efficient Consumer Response (ECR), and vertical marketing [7].

In the supply chains nowadays, e.g., in grocery sector, the greatest power is enjoyed by retail chains, and producers are dependent thereupon [2]. When a large-size retailer (retail chain) domineers in a retail chain, we may use the term "retail supply chain."

Private labels nowadays play a central role in the integration of value networks, i.e., along the value-creating chain. Additionally, the international retail chains detour local production by erecting the modern logistics-distribution centers due to large quantities they acquire at low prices [21]. That means that smaller offerers cannot participate in their value-creating chains, while the commercial concentration processes further intensify a concentration in production.

Since each product or service has a value-creating chain of its own and that an assortment comprised of various products and services is situated in retailing, retailing is an integrator of various value-creating chains. On the other hand, it is an integrator of various value-creating chains also because of the fact that it can integrate various services (logistics companies' services, banking services, Internet services, and the like) while using outsourcing.

Of course, vertical marketing systems are especially important also from the point of view of foreign-trade exchange, for the opportunities and necessities to develop entire supply chains are immediately opened by the entrance of large-sized retail chains in a country, irrespective of the fact which goods and services producers are to become these channels' members.

As the processes of concentration in an economy are being developed especially by the expansion of certain companies/groups to other countries beyond the country of origin, the internationalization of business (pertaining to both the retailers and producers) is a key initiator of changes in a retail supply chain next to an industrial consolidation. However, a dangerous concentration is being created through the expansion of international retail chains from the 
developed countries in the less developed ones, which might expel the domicile producers and retailers from the market, as they cannot adapt themselves to a new competition shortly.

Retail chains are presently significant due to their size, for they have been developed as the international ones, with their value-creating networks. Their significance grows especially because of a possibility to further expand and introduce the new technologies. The advantages of international retail chains lie in the fact that they have concentrated their functions, so that they are considerably larger than the domicile retail chains in certain countries wherein they perform.

With regard to a global international retail chain expansion, the importance of retailing is demonstrated especially concerning the countries that home the corporate headquarters in their capacities as the chain owners, for the main strategic decisions are made in their headquarters. Namely, when analyzing the significance of retailing in the individual national economies, one should take into consideration the fact that a retail company may be a link in a value-creating chain wherein the domestic and foreign producers and retailers of products (commercial merchandise) as well as of service take part [20].

The international retail chains, in the retail supply globalization processes, develop various collaborative modalities with production companies. In logistics solutions in value chains led by the large-sized retail chains, the following business models are especially interesting: (a) a global discounter, e.g., Aldi, (b) a content satisfaction retailer, e.g., Tesco, and (c) a channel retailer, e.g., Wal-Mart [19]

According to Deloitte [4], Metro AG (transacting its business in 32 countries), Carrefour (transacting its business in 31 countries), Wal-Mart (transacting its business in 28 countries), Schwarz (transacting its business in 26 countries), Tesco (transacting its business in 13 countries), etc. are pinpointed among the largest retail chains in the world in 2012. Nevertheless, the retail chains headquartered in the observed transitional countries (Croatia, Hungary, Slovakia, Czech Republic and Poland) are mostly oriented to the domicile markets. In 2012, only Agrokor (Croatia) is placed among 250 largest in the world (having realized a retail and wholesale revenue amounting to US\$ 3.9 billion doing its business in three countries).

However, from the point of view of forms, i.e., of retail business unit types, important are theses types' private labels. But a new competition is also represented by online retailers that expand internationally in their value-creating networks as well.

\section{RETAIL SignificANCE INDICATORS IN SELECT COUNTRIES}

The select indicators of distributive trade significance are depicted in table 1 and 2. From Table 1 , one may observe that distributive trade has versatile significance in individual countries based on this indicator. However, even in the less developed countries (e.g., in the Republic of Croatia) distributive trade has an almost equal significance. Nonetheless, according to the number of employees in the Netherlands and in the Republic of Croatia, retail significance is at its highest among the countries observed.

Table 2 depicts various distribution structures in certain countries. However, distributive trade (especially retailing) does not lag behind the economically more market-developed countries, according to its shares in transitional countries.

Table 1: Distributive trade shares in the overall number of employees in select countries in 2010

\begin{tabular}{|c|c|r|r|r|r|r|r|r|r|}
\hline \multirow{2}{*}{ Number } & \multirow{2}{*}{ Country } & \multicolumn{4}{|c|}{$\begin{array}{c}\text { Number of employees } \\
\text { in millions }\end{array}$} & \multicolumn{4}{|c|}{$\begin{array}{c}\text { Share in employment } \\
\text { in percentages }\end{array}$} \\
\cline { 2 - 9 } & & Total & 45 & 46 & 47 & 45 & 46 & 47 & $\mathrm{G}$ \\
\hline 1 & Austria & 4.10 & 0,08 & 0.20 & 0.34 & 1.95 & 4.88 & 8.29 & 15.12 \\
\hline 2 & Finland & 2.45 & 0.04 & 0.09 & 0.16 & 1.63 & 3.67 & 6.53 & 11.83 \\
\hline 3 & Germany & 38.74 & 0.80 & 1.82 & 3.33 & 2.06 & 4.70 & 8.60 & 15.36 \\
\hline
\end{tabular}


Logistics \& Sustainable Transport

Vol. 5, No. 1, November 2014, 1-7

doi: 10.1515/jlst-2015-0001

\begin{tabular}{|c|c|r|r|r|r|r|r|r|r|}
\hline 4 & Italy & 22.87 & 0.40 & 1.20 & 1.89 & 1.75 & 5.25 & 8.26 & 15.26 \\
\hline 5 & Netherlands & 8.37 & 0.14 & 0.50 & 0.81 & 1.67 & 5.97 & 9.68 & 17.32 \\
\hline 6 & Slovakia & 2.32 & 0.03 & 0.15 & 0.19 & 1.29 & 6.47 & 8.19 & 15.95 \\
\hline 7 & Czech Republic & 4.89 & 0.08 & 0.25 & 0.36 & 1.64 & 5.11 & 7.36 & 14.11 \\
\hline 8 & Poland & 15.47 & 0.24 & 0.74 & 1.29 & 1.55 & 4.78 & 8.34 & 14.67 \\
\hline 9 & Hungary & 3.78 & 0.07 & 0.17 & 0.32 & 1.47 & 4.50 & 8.47 & 14.44 \\
\hline 10 & Croatia & 1.54 & 0.02 & 0.09 & 0.14 & 1,30 & 5.84 & 9.09 & 16.23 \\
\hline
\end{tabular}

Table 2: Distributive trade shares in the overall number of companies in select countries in 2010

\begin{tabular}{|c|c|r|r|r|r|r|r|r|c|}
\hline \multirow{2}{*}{ Number } & \multirow{2}{*}{ Country } & \multicolumn{4}{|c|}{$\begin{array}{c}\text { Number of enterprises } \\
\text { in thousands* }\end{array}$} & \multicolumn{4}{c|}{$\begin{array}{c}\text { Share in total number } \\
\text { of enterprises in } \\
\text { percentages }\end{array}$} \\
\cline { 2 - 10 } & & Total & 45 & 46 & 47 & 45 & 46 & 47 & $G$ \\
\hline 1 & Austria & 301.7 & 9.5 & 24.3 & 40.6 & 3.14 & 8.06 & 13.46 & 24.67 \\
\hline 2 & Finland & 224.5 & 9.4 & 15.4 & 22.3 & 4.18 & 6.85 & 9.94 & 20.97 \\
\hline 3 & Germany & $2,073.9$ & 99.0 & 142.4 & 325.1 & 4.77 & 6.86 & 15.71 & 26.83 \\
\hline 4 & Italy & $3,867.8$ & 119.3 & 409.7 & 644.9 & 3.09 & 10.59 & 16.67 & 30.35 \\
\hline 5 & Netherlands & 777.9 & 27.0 & 73.0 & 93.4 & 3.47 & 9.39 & 12.01 & 24.86 \\
\hline 6 & Slovakia & 406.1 & 8.8 & 55.4 & 58.9 & 2.18 & 13.65 & 14.51 & 30.33 \\
\hline 7 & Czech Republic & 968.1 & 33.3 & 70.2 & 128.8 & 3.44 & 7.25 & 13.31 & 24.00 \\
\hline 8 & Poland & $1,480.1$ & 80.0 & 114.0 & 330.9 & 5.40 & 7.70 & 22.36 & 35.46 \\
\hline 9 & Hungary & 554.9 & 19.4 & 33.9 & 88.1 & 3.49 & 6.12 & 15.88 & 25.49 \\
\hline 10 & Croatia & 165.5 & 5.7 & 19.0 & 20.9 & 3.47 & 11.49 & 12.61 & 27.57 \\
\hline
\end{tabular}

*except financial and insurance activities

Source: Annual enterprise statistics for special aggregates of activities in [17], [6]

Table 3 depicts the GDP realization per a turnover unit in distributive trade. It is visible from Table 3 that the retail efficacy in transitional countries (Slovakia, Czech Republic, Poland, Hungary, Croatia) is smaller than in the economically more market-developed countries, because a smaller GDP is being realized per a retail turnover unit. Thus, the significance of retailing business for the overall 
economy is smaller in transitional countries, irrespective of its shares in the number of employees and in the number of companies.

Table 3: GDP per distributive trade's turnover unit in select countries in 2010

\begin{tabular}{|c|c|c|c|c|c|c|c|c|c|}
\hline \multirow{2}{*}{ Number } & \multirow{2}{*}{ Country } & \multirow{2}{*}{$\begin{array}{c}\text { GDP in } \\
\text { billions } \\
\text { of } \\
\text { Euros* }\end{array}$} & \multicolumn{3}{|c|}{$\begin{array}{c}\text { Turnover in billions } \\
\text { of Euros }\end{array}$} & \multicolumn{4}{|c|}{$\frac{\text { BDP }}{\text { Turnover }}$} \\
\hline & & & 45 & 46 & 47 & 45 & 46 & 47 & $G$ \\
\hline 1 & Austria & 285.2 & 26.5 & 135.5 & 54.9 & 10.76 & 2.08 & 5.19 & 18.03 \\
\hline 2 & Finland & 178.7 & 15.4 & 65.1 & 35.5 & 11.60 & 2.74 & 6.84 & 21.18 \\
\hline 3 & Germany & $2,495.0$ & 182.1 & $1,014.1$ & 474.4 & 13.70 & 2.46 & 5.26 & 21.42 \\
\hline 4 & Italy & $1,551.9$ & 112.2 & 528.8 & 312.6 & 13.83 & 2.93 & 4.96 & 21.72 \\
\hline 5 & Netherlands & 586.8 & 57.9 & 378.6 & 100.4 & 10.13 & 1.55 & 5.84 & 17.52 \\
\hline 6 & Slovakia & 65.9 & 4.2 & 27.1 & 16.2 & 15.69 & 2.43 & 4.06 & 22.18 \\
\hline 7 & $\begin{array}{r}\text { Czech } \\
\text { Republic }\end{array}$ & 149.9 & 13.5 & 80.1 & 35.5 & 11.10 & 1.87 & 4.22 & 17.19 \\
\hline 8 & Poland & 354.6 & 26.9 & 176.9 & 96.7 & 13.18 & 2.00 & 3.67 & 18.85 \\
\hline 9 & Hungary & 96.2 & 79.0 & 42.5 & 24.7 & 12.18 & 2.26 & 3.89 & 18.33 \\
\hline 10 & Croatia & 44.4 & 2.7 & 14.9 & 11.8 & 16.44 & 2.98 & 3.76 & 23.18 \\
\hline
\end{tabular}

*Gross domestic product at market prices

Source: [5], [6]

Namely, the international retail chains perform in these countries with merchandise and services procured on a wider international market. In any way, they have rationalized the distribution. However, while creating the supply chains of their own, they were able to avoid the domicile production and service companies in a country. Thus, for an evaluation of retail significance in a country, it is necessary to also analyze its structure with regard to the degree of concentration and retail companies' expansion to other countries.

\section{CONCLUSION}

Through the development of vertical marketing systems and their value-creating chains, retail assumes a new role, especially in the gocery sector. Thus, the necessities for new economic activity analyses emerge in certain countries due to a processes of business internationalization and globalization. This is especially important when analyzing retail importance in a country. In that sense, it is necessary to distinguish the following: (a) retail significance indicators as a distribution system constituent in a country; (b) retail significance indicators pertaining to the economic life of an individual country.

Paper not only indicates to necessity for a new approach in analyzing retail significance in overall economy, but also proposes a specific new retail significance indicator - GDP realization per a turnover unit in distributive trade. 
On the basis of available data on retail efficacy in the observed European countries, we may conclude that retail is less efficacious in transitional countries, since a lesser GDP is being realized per retail turnover unit.

\section{REFERENCES}

1. Definition of Marketing, American Marketing Association (approved Jul. 2013), available at https://archive.ama.org/Archive/AboutAMA/ Pages/DefinitionofMarketing.aspx, accessed on Apr. 3, 2014.

2. Dujak, D., "Uloga maloprodaje u upravljanju opskrbnim lancem", doctoral thesis, Josip Juraj Strossmayer University of Osijek, Faculty of Economics in Osijek, 2012.

3. Employment (Main Characteristics and Rates) - Annual Averages, available at http://appsso eurostat ec europa eu/, accessed on Apr $12,2014$.

4. Global Powers of Retailing, Deloitte, available at http://www2.deloitte.com/content/ dam/Deloitte/global/Documents/Consumer-Business/dttl-CB-GPR14STORES.pdf, accessed on Apr. 19, 2014.

5. Gross Domestic Product at Market Prices, Eurostat, available at http://epp.eurostat.ec. europa. eu/, accessed on Apr. 12, 2014.

6. Key Indicators, Wholesale, and Retail Trade: Repair of Motor Vehicles and Motorcycles (NACE Section G) 2010, B. png, available at http://epp.eurostat.ec.europa.eu/, accessed on Apr. 12, 2014.

7. Koppers, Laura and M. Klumpp, "Kooperationskonzepte in der Logistik - Synopsis zU SCM, ECR und VM, FOM Hochschule für Ökonomie und Management", Institut für Logistik- und Dienstleistungsmanagement, Schriftenreihe Logistikforschung, Band 9, Apr. 2010, Essen, available at http://www.fom.de/download/189Band9 02.pdf, accessed on Mar. 24, 2014.

8. Kotler, Ph., "Marketing Management: Analysis, Planing Implementation and Control", 9th ed., 1997 (Croatian translation 2001).

9. Kotler, Ph., Wong, V., Saunders, J. and Armstrong, G., "Principles of Marketing: Adapted as Fourth European Edition", Pearson Education Ltd., 2005, translated in Croatian by Mate, Zagreb, 2006.

10. Kotler, Ph. and K. L. Keller, "Marketing Management", Pearson Education, Inc., 2006, translated in Croatian by Mate, Zagreb, 2008.

11. Lerchenmüller, M., "Handelsbetriebslehre", Friedrich Kiehl Verlag GmbH, Ludwigshafen, Rhein, 2003.

12. Levy, M. and B. Weitz, "Retailing Management", McGraw-Hill Company, Inc., 2007

13. "Marketing systems: Functions, Agents, Enterprises and Channel," in Animal Feed Resources for Smallscale Livestock Producers, Proceedings of the Second PANESA Workshop, held in Nairobi, Kenya, Nov. 11 -

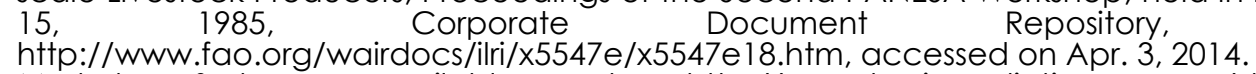

14. Market System, available at http://www.businessdictionary.com/definition/market-system. html\#ixzz2xpPNcU2d, accessed on Apr. 2, 2014

15. Multichannel Management, available at http://www.ecc-handel.de/multi-channelmanagement.php, accessed on Apr. 12, 2011.

16. NACE Rev. 2, Statistical Classification of Economic Activities in the European Community, Eurostat, Methodologies and Working Papers, European Communities, 2008, available at http://epp.eurostat.ec.europa.eu/cache/ITY_OFFPUB/KS-RA-07-015/EN/KS-RA-07-015-EN.PDF, accessed on Apr. 12, 2011.

17. Oehme, W., "Handels-Marketing", 2nd ed., Verlag Franz Wahlen, Munich, 1992.

18. Rudolph, Th., "Modernes Handelsmanagement", Schäffer Poeschel Verlag, Stuttgart, 2009

19. Segetlija, Z., "Nove tehnologije i razvoj maloprodajnih oblika," in Segetlija, Z., Karić, M. (eds.), Poslovna logistika u suvremenom menadžmentu: zbornik radova 10. međunarodnog znanstvenog skupa, Faculty of Economics in Osijek, 2010, pp. 125 - 145.

20. Bormann, Sarah; Siegel, G.: Konzentrationsprozeß im Einzelhandel, 2007 [dostupno na: www.sabinezimmermann.info, pristup 22.06.201 1.]

\section{AUTHORS}

A. Zdenko Segetlija, Ph.D. is Full Professor at Josip Juraj Strossmayer University of Osijek, Faculty of Economics in Osijek, Trg Ljudevita Gaja 7, Osijek, Croatia (e-mail: seget@efos.hr).

B. Josip Mesarić, Ph.D., is Full Professor at Josip Juraj Strossmayer University of Osijek, Faculty of Economics in Osijek, Trg Ljudevita Gaja 7, Osijek, Croatia (e-mail: mesaric@efos.hr).

C. Davor Dujak is Assistant Professor at Josip Juraj Strossmayer University of Osijek, Faculty of Economics in Osijek, Trg Ljudevita Gaja 7, Osijek, Croatia (e-mail: ddujak@efos.hr). 